Case Study

https://doi.org/10.20546/ijcmas.2019.807.141

\title{
Dystocia due to Schistosomus Reflexus Holstein Friesian Fetal Monster in a Gir Heifer
}

\author{
V. Varudharajan*, M. Selvaraju, S. Prakash, K. Ravikumar, \\ D. Gopi Krishnan and K. Senthil Kumar
}

Department of Veterinary Gynaecology and Obstetrics, Veterinary College and Research
Institute, TANUVAS, Namakkal - 637001, Tamil Nadu, India

*Corresponding author

\section{A B S T R A C T}

\section{Keywords \\ Dystocia, Gir, \\ Heifer, \\ Schistosomus \\ reflexus \\ Article Info \\ Accepted: \\ 10 June 2019 \\ Available Online: \\ 10 July 2019}

\section{Introduction}

Schistosomus reflexus is a rare type of fetal monster primarily seen in cattle and rare in small ruminants especially in ewes (Dennis, 1965).

Schistosomus reflexus is a developmental defect characterized by a marked ventral curvature of the spine, deformed pelvis and the body and chest walls bent laterally with exposed thoracic and abdominal viscera (Roberts, 2004). Fetotomy or caesarean section is mandatory for delivery of a fully grown schistosomus reflexus monster while, per-vaginal expulsion without any obstetrical assistance is noticed in small sized monster fetuses (Kalita et al., 2004).

\section{Case History and Clinical Observations}

A three years old Gir heifer was brought to the Veterinary Clinical Complex, VCRI, Namakkal with the history of dystocia since 12 hours. Clinically, the fetal abdominal viscera were protruding out of the vulva (Fig. 1). Vaginal examination revealed fully dilated cervix, dry and edematous vaginal passage. Detailed examination revealed presence of schistosomus reflexus fetus in transverse 
presentation. Thus, the case was diagnosed as dystocia due to schistosomus reflexus fetal monster.

\section{Clinical Management}

The animal was restrained in the hind quarter elevator for easy handling and administered with $3 \mathrm{ml}$ of $2 \%$ lignocaine in the sacrococcygeal space to attain epidural anesthesia. Enough lubrication with cetrimide cream, the viscera of the fetus was separated first. Then traction was applied on both the fore limbs along with head and repulsion of both hind limbs inside the uterus, the fetal monster was delivered along with the fetal membranes. A female schistosomus reflexus Holstein Friesian fetus was delivered along with its exposed viscera (Fig. 2). After the delivery of the fetus, the dam was administered with Inj. Calcium Borogluconate $450 \mathrm{ml}$, Inj. 25\% Dextrose 2 liters and Inj. Oxytocin 30 IU intravenously followed by Inj. Ceftriaxone 4.5 gm and Inj. Chlorpheniramine maleate $12 \mathrm{ml}$

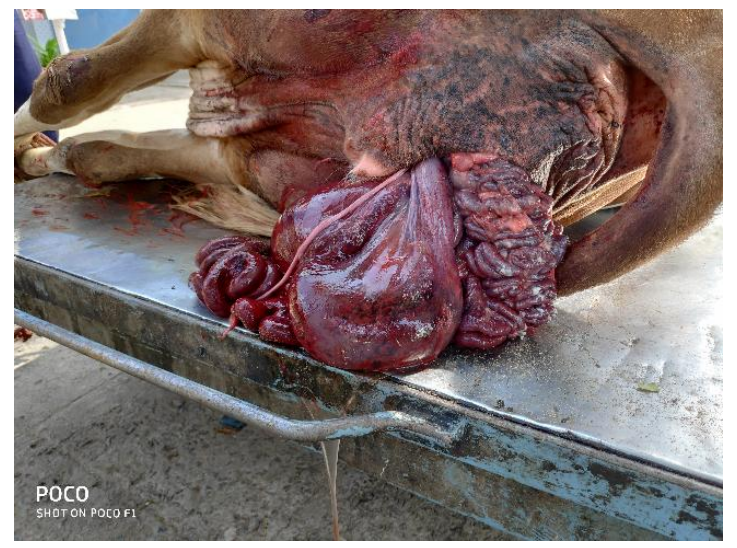

Fig. 1 Abdominal viscera of the fetus protruding through the vulva

An unusual case of dystocia due to Schistosomus reflexus Holstein Friesian fetal monster in a Gir heifer and its successful pervaginal delivery was reported in the present study. intramuscularly. Uneventful recovery of the dam was noticed.

\section{Results and Discussion}

Gross examination of the fetus revealed marked ventral curvature of the spine. The body and chest walls were stretched. The diaphragm attachment was incomplete. The lung was small and liver was enlarged. The fore limbs and hind limbs were ankylosed. Similar findings were reported by Prakash et al., (2017) and Prasad et al., (2012) in cattle. The exact cause of such type of dystocia is still unknown. It could have occurred due to the teratogenic predisposition. The possibility of genetic predisposition cannot be ignored. The interplay of multiple genes is a frequent and most important genetic mechanism for the occurrence of such extensive anomalies as described by Jana and Ghosh (2001). In the present case signifies the delivery of Schistosomus reflexus Holstein Friesian fetal monster from a Gir heifer.

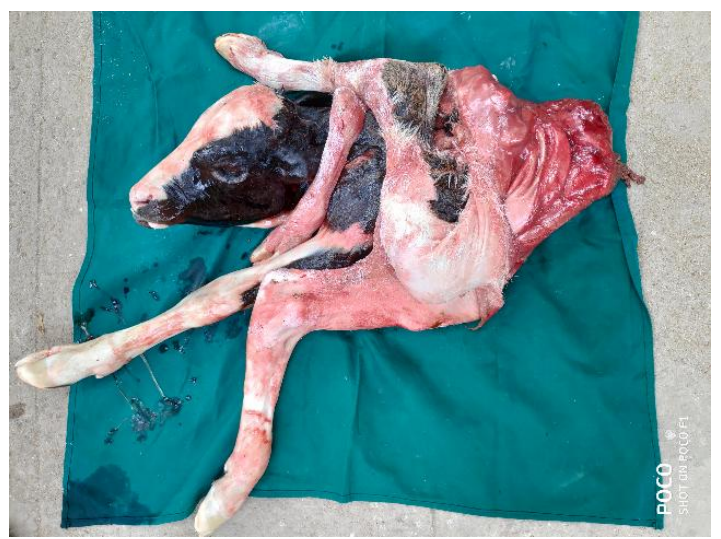

Fig. 2 Schistosomus reflexus Holstein Friesian fetus delivered from a Gir heifer

\section{References}

Dennis, S.M. and Mayer, E.P. (1965). Schistosomus reflexus in a sheep. Vet. Rec. 77: 1386. 
Jana, D and Ghosh, M. (2001) Dystocia due to fetal monster with Schistosomus reflexus and ectopic viscera- a case report. Indian Vet. J, 78: 333-334.

Kalita, D., Bhuyan, D., Mukit, A. and Islam, S. (2004). Dystocia due to Schistosomus reflexus in a goat. Indian J. Anim. Reprod. 25 (1): 76-77.

Prakash, S., Selvaraju, M., Ravikumar, K and Palanisamy, M (2017) Dystocia due to Schistosomus reflexus fetus in Heifers a report of two cases. Ind. Vet. J, 94 (02): 79-80.
Prasad, J.K., Ghosh, S.K., Kumar, B., Krishnappa, B., Ramteke, S., Rakesh, H.B., Sharma, G.C and Singh, M. (2012). Dystocia due to atypical Schistosomus Reflexus Fetus with Roman nose in Murrah Buffalo. Ind. Vet. J, 89 (10): 91.

Roberts, S.J. (2004). Veterinary Obstetrics and Genital Diseases (Theriogenology). $2^{\text {nd }}$ Edn. CBS Publishers and Distributors, New Delhi, India. pp: 300335.

\section{How to cite this article:}

Varudharajan, V., M. Selvaraju, S. Prakash, K. Ravikumar, D. Gopi Krishnan and Senthil Kumar, K. 2019. Dystocia Due to Schistosomus Reflexus Holstein Friesian Fetal Monster in a Gir Heifer. Int.J.Curr.Microbiol.App.Sci. 8(07): 1190-1192. doi: https://doi.org/10.20546/ijcmas.2019.807.141 